\title{
Global Expression Studies of Yersinia Pestis Pathogenicity
}

E. Garcia, V. Motin, R. Brubaker, P. Fitch

\section{October 15, 2002}

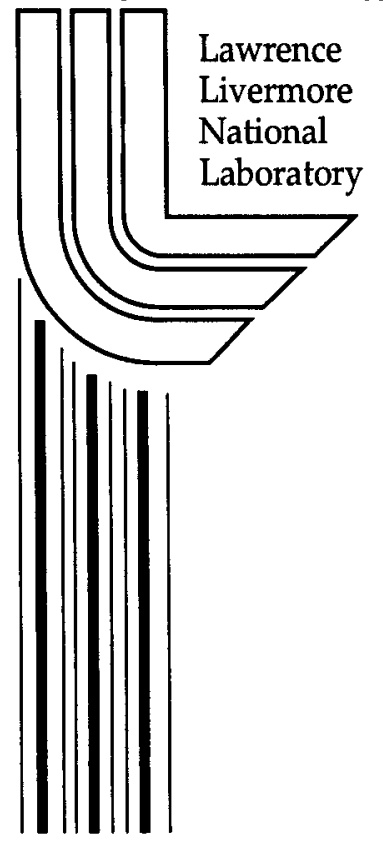




\section{DISCLAIMER}

This document was prepared as an account of work sponsored by an agency of the United States Government. Neither the United States Government nor the University of California nor any of their employees, makes any warranty, express or implied, or assumes any legal liability or responsibility for the accuracy, completeness, or usefulness of any information, apparatus, product, or process disclosed, or represents that its use would not infringe privately owned rights. Reference herein to any specific commercial product, process, or service by trade name, trademark, manufacturer, or otherwise, does not necessarily constitute or imply its endorsement, recommendation, or favoring by the United States Government or the University of California. The views and opinions of authors expressed herein do not necessarily state or reflect those of the United States Government or the University of California, and shall not be used for advertising or product endorsement purposes.

This work was performed under the auspices of the U. S. Department of Energy by the University of California, Lawrence Livermore National Laboratory under Contract No. W-7405-Eng-48.

This report has been reproduced directly from the best available copy.

Available electronically at http://www.doc.gov/bridge

Available for a processing fee to U.S. Department of Energy

And its contractors in paper from

U.S. Department of Energy

Office of Scientific and Technical Information

P.O. Box 62

Oak Ridge, TN 37831-0062

Telephone: (865) 576-8401

Facsimile: (865) 576-5728

E-mail: reports@adonis.osti.gov

Available for the sale to the public from

U.S. Department of Commerce

National Technical Information Service

5285 Port Royal Road

Springfield, VA 22161

Telephone: (800) 553-6847

Facsimile: (703) 605-6900

E-mail: orders@ntis.fedworld.gov

Online ordering: http://www.ntis.gov/ordering.htm

OR

Lawrence Livermore National Laboratory

Technical Information Department's Digital Library

http://www.llnl.gov/tid/Library.html 


\section{CBNP FY02 Annual Report}

\section{Global Expression Studies of Yersinia pestis pathogenicity}

\section{Project Personnel:}

Emilio Garcia, Lawrence Livermore National Laboratory, e-mail: garcia12@llnl.gov

Vladimir Motin, Lawrence Livermore National Laboratory, e-mail: motin1@1lnl.gov

Co-investigators: Robert Brubaker, Michigan State University

Patrick Fitch, Lawrence Livermore National Laboratory 


\section{Objectives.}

The aim of these studies continues to be the investigation into the molecular mechanisms that underlie the virulence process in Yersinia pestis. In particular, the focus of this work centers on the identification of novel genes and pathways responsible for the pathogenic properties of this organism. In spite of more than four decades of intense investigation in this field, the dilemma as to what makes $Y$. pestis such a virulent and lethal pathogen remains unanswered. The method being employed makes use microarray technology (DNA chip) that enables the examination of the global activities of the whole complement of genes in this pathogen. Two primary resources available to the investigators (one directly obtained from a separate CBNP-funded project) make these studies possible: 1) Whole genome comparisons of the genes in $Y$.pestis and its near neighbors with attenuated or non pathogenic characteristics, and 2) the ability to duplicate in vitro, conditions that mimic the infection process of this pathogen. This year we have extended our studies from the original work of characterizing the global transcriptional regulation in $Y$. pestis triggered during temperature transition from $26_{i} \mathrm{C}$ to $37 \mathrm{C}$ (roughly conditions found in the flea vector and the mammalian host, respectively) to studies of regulation encountered during shift between growth from conditions of neutral $\mathrm{pH}$ to acidic $\mathrm{pH}$ (the latter conditions, those mimic the environment found inside macrophages, a likely environment found by these cells during infection.).

For this work, DNA arrays containing some 5,000 genes (the entire genome of $\zeta$. pestis plus those genes found uniquely in the enteropathogen, and near neighbor, $Y$. pseudotuberculosis) are used to monitor the simultaneous expression levels of each gene of known and unknown function in $Y$. pestis. Those genes that are up-regulate under the experimental conditions represent genes potentially involved in the pathogenic process. The ultimate role in pathogenicity of those candidate genes uncovered from these studies will be further ascertained by direct knock outs (gene inactivation) and by in vivo studies using an animal model.

Discovery of new virulence factors in $Y$. pestis will directly impact the development of new signatures for detection and geo-location since it will help us to understand and identify those genes that essential in making the organism pathogenic. These are genes that cannot be altered or removed from the pathogen and as such constitute the best type of signature that we can utilize in their detection and identification. Applications such as this will also enable the utilization of similar technologies to study other pathogens such as Francisella and Brucella, for which we know substantially less in terms of their modality of virulence.

\section{FY02 progress:}

In the past year, reliable, high-yield method for mRNA isolation and purification that generates sufficient amounts of RNA free of DNA and protein contaminants have been developed. Appropriate buffered media that would enable transition experiments at 
varying $\mathrm{pH}$ starting at neutrality and extending to $\mathrm{pH} 4.0$ were designed and optimized. These experiments determined that the lowest $\mathrm{pH}$ at which $Y$. pestis still shows substantial growth is $\mathrm{pH} 5.5$ (Fig.1). Growth experiments during $\mathrm{pH} 7$ to 5.5 shift were conducted for both $Y$. pestis and Y. psudotuberculosis under the identical conditions and appropriate hybridizations against the 5,000-gene chip were performed with RNA obtained at 1 and $4 \mathrm{hrs}$ after the shift.

These preliminary experiments have lead the discovery of some 37 genes that are up-regulated at pH 5.5 (at least 2 fold with a 2-46-fold range) and some 38 genes that are up-regulated at $\mathrm{pH} 4.0$ (see Table 1 for selected $\mathrm{pH}$ regulated genes). Noteworthy among the genes up-regulated at $\mathrm{pH} 5.5$ are: the $\mathrm{pH} 6$ antigen precursor, an adhesin that has been previously known to be up-regulated at acidic $\mathrm{pH}$, and the three subunits encoding the enzyme urease. Interest ling, the urease is often no-functional in $Y$. pestis on account of a defect in one of the genes required for urease expression. It was furthermore discovered that both the catalase gene ( KatA) and the catalase-peroxidase gene ( $k a t Y$ ) two enzyme presumably contributing to detoxification of free radicals and damaging oxygen species produced in macrophages were both up-regulated. This finding supports the likely involvement of these enzymes in the virulence process. At least five genes encoding proteins with no known function were determined to be up-regulated at $\mathrm{pH} \mathrm{5.5.} \mathrm{These} \mathrm{are}$ potential good candidates for genes having a role in pathogenicity in $Y$. pestis and will be further examined by knockouts and animal studies (as a result of these, and related CBNP and internally funded studies of this nature, an NIH grant has been awarded to V. Motin to conduct these type of studies). Those genes up-regulated at pH 5.5 are an entirely different set of genes than those up-regulated at $\mathrm{pH}$ 4.0. At least 14 genes found only in $Y$. pseudotuberculosis were upregulated at this latter $\mathrm{pH}$ and only 4 genes of this organism were up-regulated at $\mathrm{pH}$ 5.5.

A subset of genes that is both regulated during $\mathrm{pH}$ shift as well as during temperature shift has been identified. This set might represent the best new candidate virulence genes found by these studies.

In parallel with the bacterial response during conditions mimicking infection, and with the support of internal laboratory funding (LDRD), we have begun work to study the host response to Yersinia infection. For this work human dendritic cells in culture have been subject to infection by several Yersinia species. Using commercially available DNA chips (Affymetrix) containing 1000s of human genes we have determined the transcriptional response mounted by the human cells in culture during Yersinia infection. A pattern of genes that respond at 1,2,4 and $10 \mathrm{hrs}$ after $Y$. pestis infection are shown in Figure 1). We expect that a differential pattern of response to a given pathogen, might allow in the future the development of an early warning system for exposure to BW agents.

Future Outlook: Next year we will continue validating the results obtained during temperature and $\mathrm{pH}$ shift experiments. Some of these putative genes uncovered may be 
tested by direct knockouts. However, much work in the area of temperature and $\mathrm{pH}$ response remains to be done. We will focus our efforts at studying the effect on the expression patterns of known $Y$. pestis mutants affected in virulence. Such studies will serve to potentially elucidate the steps in the virulence pathway affected by these mutations. We will direct the best part of our effort to study host response using knockouts: the effects of various virulence factors on cellular response will be analyzed using knockout strains of $Y$. pestis in dendritic cells. We will compare a strain lacking the $\mathrm{V}$ antigen which causes an anti-inflammatory response (Motin et al 1995) to wild type as well as strain lacking other activities encoded by unique genes of $Y$. pestis (these have been identified by our $Y$. pseudotuberculosis- $Y$. pestis comparative sequencing (manuscript in preparation). These types of experiments should shed important light into the virulence pathway of $Y$. pestis.

Finally, we will undertake comparative host response to various pathogens: We plan to study the response of two strains related to $Y$. pestis; $Y$. enterocolitica, and $Y$. pseudotuberculosis. Although genetically very similar to $Y$. pestis, they do not cause plague. We will compare the expression profiles of these related strains in dendritic and other appropriate cells to understand how the cellular response to these pathogens differs. Pathogen with a different virulence mechanism (Brucella abortus, Francisella tularensis and hantavirus) will be used to extend the spectrum of response being examined.

\section{Project report sidebars}

By unraveling the pathways that contribute to virulence, it will be possible to elucidate the reasons why this plague-causing bacterium is so virulent and lethal.

Understanding what human genes get activated first during bacterial infection will help the development of methods for early warning and detection.

\section{Citations}

1. V.L. Motin, Georgescu A.M., Fitch J.P., Gu P.P., Coleman M.A., Garnham J.B., Sokhansanj B.A., Ott L.L., Elliott J.M., Kegelmeyer L.M., Wyrobek A.J., Slezak T.R., Brubaker R.R., and Garcia E. DNA Microarray Analysis of Differential Gene Expression in Yersinia pestis. (Abstract) Eight International Symposium on Yersinia, Turku, Finland, Sept. 4-8. 2002. (URL-JC-148073-ABS)

2. V.L. Motin, A.M. Georgescu, J.P. Fitch, J.B. Garnham, B.A. Sokhansanj, L.L.Ott, M.A. Coleman, B.J. Marsh, J.M. Elliott, L.M. Kegelmeyer, A.J. Wyrobeck, T.R. Slezak, R.R. Brubaker, and E. Garcia. Genome-Wide Expression Profiling of Yersinia pestis During Low-Calcium Response. Abstracts, p. 159.The 102th General Meeting of the American Society for Microbiology, Salt ${ }^{\circ}$ Lake City, UT, May 19-23. 2002. (UCRLJC-146479-ABS) 
3. Motin, V.L. Georgescu, A., Elliott, J. Hu, P., Worsham, P.L. Song, J., Brubaker, R.R. and E. Garcia. 2002. Genetic Variability of Yersinia pestis Isolates as Predicted by PCRbased IS100 Genotyping and Analysis of the Structural Gene Encoding Glycerol-3Phosphate Dehydrogenase ( $g l p D)$., J. Bacteriol.184:1019-1027

4. Iwobi, A., Rakin, A., Garcia, E., Heesemann, J. 2002. Representational difference analysis uncovers a novel IS 10 -like insertion element unique to pathogenic strains of Yersinia enterocolitica. FEMS Microbiol. Letters 210:251-255. 
Figure 1 (Garcia, E.)

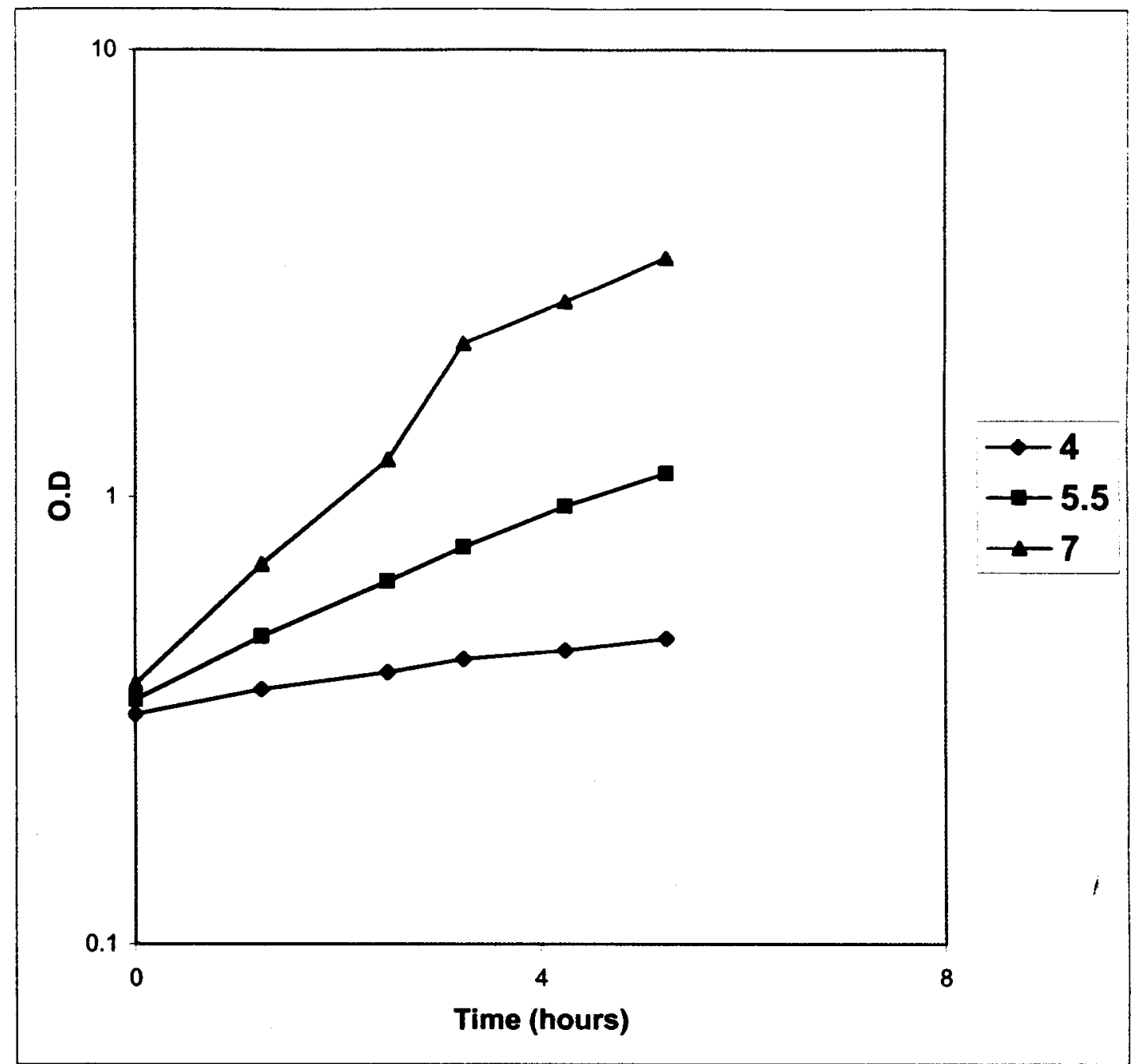

Figure 1. Growth Curve of $Y$. pestis cells grown at different $\mathrm{pH}$ 
Groupl. 183 genes up-regulated after

$1 \mathrm{hr}$ expostre, returned to normal $4 \mathrm{hrs}$.

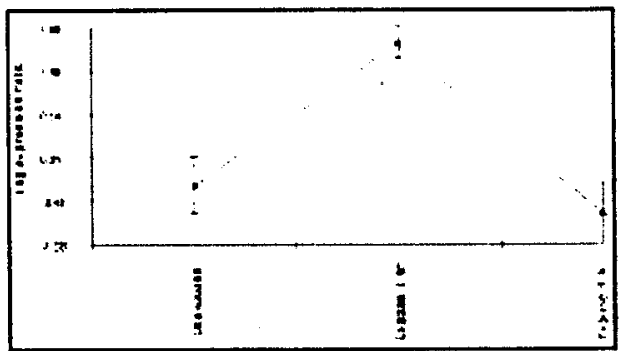

Croup3. 229 genes up-regulated after $1 \mathrm{hr}$ exposure, further eievated $4 \mathrm{hrs}$.

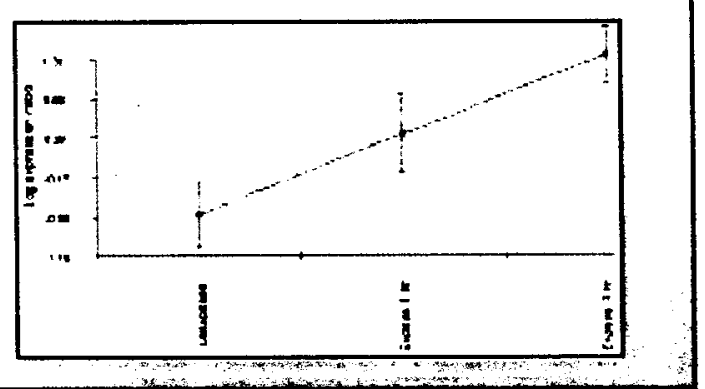

Group2. 175 down-regulated after

$1 \mathrm{hr}$ exposure, returned to normal of $4 \mathrm{hrs}$.

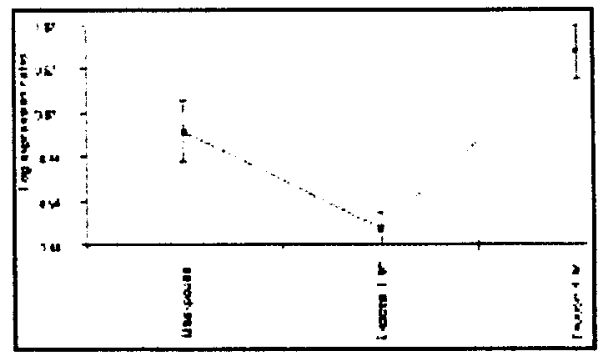

Group4. 140 down-regulated after $1 \mathrm{hr}$ exposure, further repressed $4 \mathrm{hrs}$.

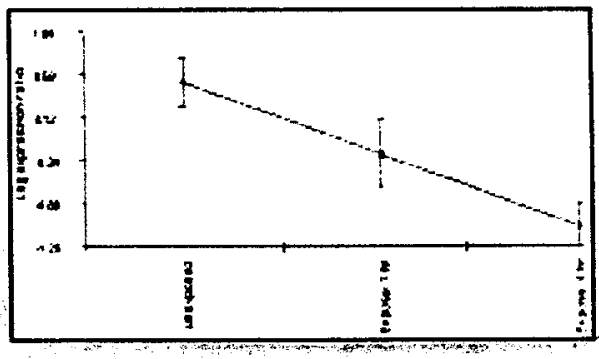


Genes in $Y$. pestis induced at $\mathrm{pH} 5.5(>2$ fold $)$

\begin{tabular}{|l|l|c|}
\hline Gene name & Product/Function & Fold (ratio) \\
\hline YPO1303 & pH 6 antigen precursor (antigen 4) (adhesin) & 46.14 \\
\hline YPO2667 & urease alpha subunit & 7.33 \\
\hline YPO2665 & urease gamma subunit & 6.36 \\
\hline YPO1304 & chaperone protein PsaB precursor & 5.97 \\
\hline YPO2666 & urease beta subunit & 4.24 \\
\hline YPO3098 & probable glycosyltransferase & 3.63 \\
\hline YPO2668 & urease accessory protein & 3.54 \\
\hline YPO0833 & putative phospho-sugar isomerase & 3.35 \\
\hline YPO2672 & putative urea transporter & 3.23 \\
\hline YPO3716 & maltose transport system permease protein MalG & 3.13 \\
\hline YPO3987 & putative exported protein & 2.82 \\
\hline YPO2221 & aconitate hydratase 1 & 2.59 \\
\hline YPO1994 & hypothetical protein & 2.56 \\
\hline YPO2671 & urease accessory protein (pseudogene) & 2.52 \\
\hline YPO1996 & hypothetical protein & 2.48 \\
\hline YPO1995 & hypothetical protein & 2.48 \\
\hline YPO3950 & putative membrane protein & 2.38 \\
\hline YPO1783 & Ferritin & 2.25 \\
\hline RpOH & Heat shock sigma factor & 2.22 \\
\hline YPO2680 & PTS system, cellobiose-specific IIA component & 2.21 \\
\hline YPO2540 & putative thermosensitive gluconokinase & 2.20 \\
\hline YPO1207 & Catalase (katA) & 2.14 \\
\hline YPO2678 & PTS system, cellobiose-specific IIB component & 2.12 \\
\hline YPO3319 & catalase-peroxidase & 2.09 \\
\hline YPO3370 & cysH-phosphoadenosine phosphosulfate reductase & 2.05 \\
\hline YPO2754 & conserved hypothetical protein & 2.03 \\
\hline YPO1831 & flagellar hook-basal body complex protein FliE & 2.03 \\
\hline & & \\
\hline
\end{tabular}

\section{Genes induced at pH 4.0 ( $>2$ fold)}

\begin{tabular}{|l|l|c|}
\hline Gene name & Product/Function & Fold (ratio) \\
\hline YPO2241 & putative exported protein & 5.21 \\
\hline YPO2027 & conserved hypothetical protein (pseudogene) & 2.14 \\
\hline YPO3474 & hypothetical protein & 2.10 \\
\hline Y1042_orf81 & NA & 2.10 \\
\hline YPO0238 & mechanosensitive ion channel & 2.09 \\
\hline YPO1383 & formate acetyltransferase 1 & 2.06 \\
\hline YenI & NA & 2.04 \\
\hline YPO2142 & Na+/H+ antiporter & 2.04 \\
\hline
\end{tabular}

* Genes in bold may be involved in virulence and/or were induced also at $37_{i} \mathrm{C}$ 